\title{
ŽEMĖS SKLYPŲ PERTVARKYMO PATYRIMAS PLANUOJANT MIESTUU TERITORIJAS
}

\author{
Evaldas Ramanauskas ${ }^{1}$, Liucijus Dringelis ${ }^{2}$ \\ ${ }^{1,2} \mathrm{KTU}$ Architektūros ir statybos institutas, Teritoriju planavimo centras, \\ Tunelio g. 60, 44405 Kaunas, Lietuva \\ El.paštas: ${ }^{1}$ evaldas.ramanauskas@ktu.lt, ${ }^{2}$ krastotvarka@asi.lt
}

Iteikta 2011-10-21

\begin{abstract}
Santrauka. Šiuo metu planuojant miestus daugeliu atvejų susiduriama su anksčiau susiklosčiusių žemès sklypų struktūra, kuri yra visiškai netinkama naujoms miestų teritorijoms formuoti. Vienos pagrindinių priemonių tokiai struktūrai pertvarkyti yra bendrieji bei detalieji planai. Bendraisiais, detaliaisiais planais žemès sklypų struktūra pertvarkoma numatant statybines, viešąsias teritorijas, nustatant naujas žemės sklypų naudojimo paskirtis, jų atskiras dalis paskirstant ị skirtingas funkcines zonas, numatant statybines teritorijas, rezervuojant teritorijas visuomenès poreikiams ar pan. Detaliaisiais planais - suformuojant atskirus žemės sklypus, išskiriant visuomenès poreikiams reikalingų teritorijų žemės sklypus, numatant teritorijos naudojimo bei tvarkymo režimus ir pan. Tačiau šiais planavimo dokumentais žemès sklypų struktūra pertvakoma ne visada sẻkmingai. Iškyla problemų, susijųsių su harmoningu teritorijų suplanavimu bei viešųjų, visuomeninių teritorijų suformavimu. Galimybės rengti mažo ploto sklypų detaliuosius planus dažnai neleidžia ịvertinti visumos, kompoziciškai darnios erdvinès struktūros sukūrimo. O labai sudètingos žemės visuomenės poreikiams paėmimo procedūros lemia, kad dažnai nẻra sukuriamos tinkamos teritorijos poilsiui, sportui, kitiems visuomeniniams objektams.

Straipsnyje, siekiant išryškinti miestų planavimo problemas ir ịvertinti jų sprendimo galimybes, pasitelkiama tarpukario Lietuvos, taip pat užsienio šalių teritorijų planavimo patirtis. Šiuo tikslu pristatomas tarpukario Lietuvoje naudotas, o užsienyje ir šiuo metu taikomas žemės tvarkymo metodas bei svarbiausi jo uždaviniai. Kaip viena iš užsienio šalių, turinti didžiausią patirtį žemės pertvarkymo srityje, plačiau apžvelgiama Vokietija.
\end{abstract}

Reišminiai žodžiai: teritorijų planavimas, urbanistinis vystymas, žemės pertvarkymas, visuomenès interesas, įstatymų bazè.

\section{Ivadas}

Teritorijų planavimo procese privačios žemès nuosavybès sąlygomis neišvengiamai susiduriama su prieštaringais privačiaisiais bei viešaisiais interesais. Šiuo aspektu planuojant miestus vieni aktualiausių klausimų kyla sprendžiant visuomenei reikalingų teritorijų suformavimą, kuriant naujas racionalias urbanistines struktūras, taip pat siekiant modernizuoti esamas užstatytas miestų dalis. Šie klausimai tiesiogiai susiję su privačių žemès sklypų pertvarkymu, žemès paèmimu visuomenès poreikiams.

Žemès pertvarkymo problemos planuojant miestus yra plačiai nagrinejjamos užsienyje G. Larson, K. Viitenen, J. Sonnenberg, A. Sorensen, S. Gil ir kt. Lietuvoje dabartiniu metu šis klausimas daugiau ar mažiau paliečiamas urbanistų, teritorijų planavimo, žemès ūkio vystymo specialistų (D. Bardauskienè, M. Pakalnis, Z. J. Daunora, E. Staniūnas, M. Burinskienė, P. Aleknavičius, straipsnio autorių darbuose ir kt.). Žemès pertvarkymo būtinybe iškeliama urbanistiniuose forumuose (Darnioji... 2008), naujai rengiamuose teritorijų planavimo teisiniuose dokumentuose: naujos redakcijos Teritorijų planavimo ịstaty tmo koncepcijoje (2010), Miestų, miestelių ir kaimų (gyvenamųjų vietovių) planavimo normų projekte (2008).

Šio straipsnio tikslas taip pat yra prisidèti prie teritorijų planavimo proceso analizès, jo tobulinimo būdų ieškojimo. Šalies teritorijų planavimo ir žemès tvarkymo būklè šiame straipsnyje įvertinama remiantis teritorijų planavimo įstatymais, rengiamais bei parengtais teritorijų planavimo dokumentais, vykstančiais kraš- 
tovaizdžio pokyčiais, pačių autorių patyrimu. Užsienio šalių žemės tvarkymo planuojant miestus patirtis apžvelgiama remiantis analitiniais užsienio autorių tyrimais, taip pat analizuojant teisinius užsienio šaliu dokumentus.

\section{Esama šalies miestų teritorijų planavimo būklè}

Šiuo metu miestų žemès sklypai daugiausia naudojami ir tvarkomi pagal bendruosius bei detaliuosius teritorijų planus. Bendraisiais planais kompleksiškai nustatomos teritorijų funkcinès zonos, numatomos priemonès urbanistinei kompozicijai tobulinti, formuojama bendro naudojimo želdynų sistema, rezervuojamos teritorijos, reikalingos visuomenés poreikiams, kt. Detaliaisiais planais detalizuojami bendruosiuose planuose numatyti teritorijų tvarkymo ir naudojimo reikalavimai, formuojami žemès sklypai, kt. (Lietuvos Respublikos... 1995). Apskritai, šių planavimo dokumentų rengimas pagrịstas planavimo kokybe - formuoti sveiką ir harmoningą gyvenamąją, darbo ir poilsio aplinką. Tačiau techniniu požiūriu, rengiant planus miestams, yra tam tikrų spragų, dèl kurių planavimo kokybė dažnai nukenčia. Šias spragas galima sieti su: 1) teritoriniu nenuoseklumu, kuris atsiranda tarp bendruju planu sprendiniu ir ju sprendinius konkretizuojančių detaliųjų planų, 2) neefektyviomis priemonemis viešosioms teritorijoms formuoti.

Teritorinis nenuoseklumas tarp bendrųjų ir detaliųjų planų atsiranda bendraisiais planais planuojant labai dideles teritorijas (rajonus, miestus), o detaliaisiais planais labai mažas (atskirus žemès sklypus nepriklausomai nuo jų didumo (pagal Lietuvos Respublikos... 1995). Miestų bendruosiuose planuose, daugiausia rengiamuose nuo M 1:25000 iki M 1: 5000, pateikiamas teritorijos suplanavimas gali apsiriboti svarbiausiais teritorijos suplanavimo sprendiniais - nurodant $\mathrm{A}, \mathrm{B}, \mathrm{C}$ kategorijos gatves, vyraujančią teritorijos naudojimo paskirti (Miestu, miestelių... 2006). Urbanistiniu požiūriu toliau turètų būti parengtas atskiras miestų dalis detalizuojantis teritorijos suplanavimas. Tačiau, kaip rodo patyrimas, šiuo metu toks vientisas didelių teritorijų detalizavimas dažnai nèra rengiamas. Remiantis principiniais bendrujų planų sprendiniais (net ir rajonų, jei nèra padaryta mažesnių teritorijų - miestų, miestelių bendrųjų planų!), dažniausiai yra rengiami atskirų žemès sklypų detalieji planai.

Atskiriems žemès sklypams rengiami detalieji planai paprastai nesudaro galimybių kompleksiškai pertvarkyti didesnès vientisos teritorijos žemès sklypų, numatyti harmoningo naujų statybinių žemès sklypu išdėstymo, bendro naudojimo erdvių sistemos. Visas teritorijos urbanistinis vystymas dažniausiai apsiri- boja tik atskiro žemės sklypo ribose, numatomas tik tam sklypui racionaliausias sudalinimas ị mažesnius statybinius sklypus, nevertinant platesnio konteksto. Keičiant atskirų žemès sklypų naudojimo paskirtị, paprastai išlieka pirmine sklypo forma, jo vieta, nepaisant to, kad sklypo konfigūracija bei išsidèstymas yra netinkami kvartalų grupei ar gyvenamajam rajonui plètoti (pavyzdžiui, iš žemės ūkio paskirties sklypų, kurie yra ivvairiausios daugiakampès, rèžinės konfigūracijos, formuojami gyvenamosios paskirties ar kiti statybiniai sklypai) (1 pav.).

Toliau svarbu pabrèžti, kad rengiant teritorijų planavimo dokumentus susiduriama su nemažomis probelmomis, kylančiomis rezervuojant teritorijas visuomenès poreikiams. Dèl jų yra labai sunku sukurti reikiamą kiekị viešųjų teritorijų, reikalingų gatvèms, praejjimams, skverams, parkams, sporto, žaidimo aikštelëms bei kitoms visuomeninèms teritorijoms irengti.

Pagal bendrųjų planų sprendinius vieni sklypai tiesiog patenka visu savo plotu i statybines teritorijas, o kiti ištisai yra užimami visuomeninio pobūdžio teritorijų (2 pav.). Siekiant suformuoti viešąsias teritorijas, savivaldybèms reikalinga privačius žemès sklypus išpirkti. Tačiau tai sudaro dideles išlaidas. Be to, dažnai kyla žemès savininkų, iš kurių reikalinga išpirkti žemę, pasipiktinimas. Jų pasipiktinimas kyla dèl to, kad jie iš planavimo dažnai negali gauti tiek naudos, kiek jos gali gauti žemės savininkai, iš kurių žemè neišperkama. Tai ryškiausia tais atvejais, kada bendra suplanuotos teritorijos vertè rinkoje pakyla, pavyzdžiui, vietoj žemès ūkio paskirties teritorijos formuojant gyvenamąsias, komercines teritorijas ar pan., o visuomenès poreikiams reikalingos teritorijos išperkamos ịvertinant tik pirminès žemès paskirties rinkos kainas (Lietuvos Respublikos žemès... 2011).

Reakcija, kylanti dèl galimo atskirų žemès sklypų vertès išsiskyrimo, taip pat savivaldybių nenoras ịsipareigoti išpirkti viešąsias teritorijas labai apsunkina teritorijų planavimą. Todèl dažniausiai visuomenès poreikiams yra rezervuojami tik patys būtiniausi susisiekimo elementai, tokie kaip gat vès, keliai, atsisakant gausesnių želdynų plotų, rekreacinių teritorijų bei kitų atvirų viešųjų erdvių.

\section{Tarpukario miestų žemės planavimo patyrimas}

Panašių problemų buvo iškilę ir tarpukario Lietuvoje. Miestams vystyti ir plèsti taip pat trukde privatūs žemès sklypai bei skirtingi žemès savininkų interesai.

Paskelbus Lietuvos nepriklausomybę 1918 m., miestuose buvo susiklosčiusi gana chaotiška situacija daugelis miestų šalyje buvo nukentejję nuo karo, be to, ankstesniu carinès Rusijos laikotarpiu nemaža miestų 
A

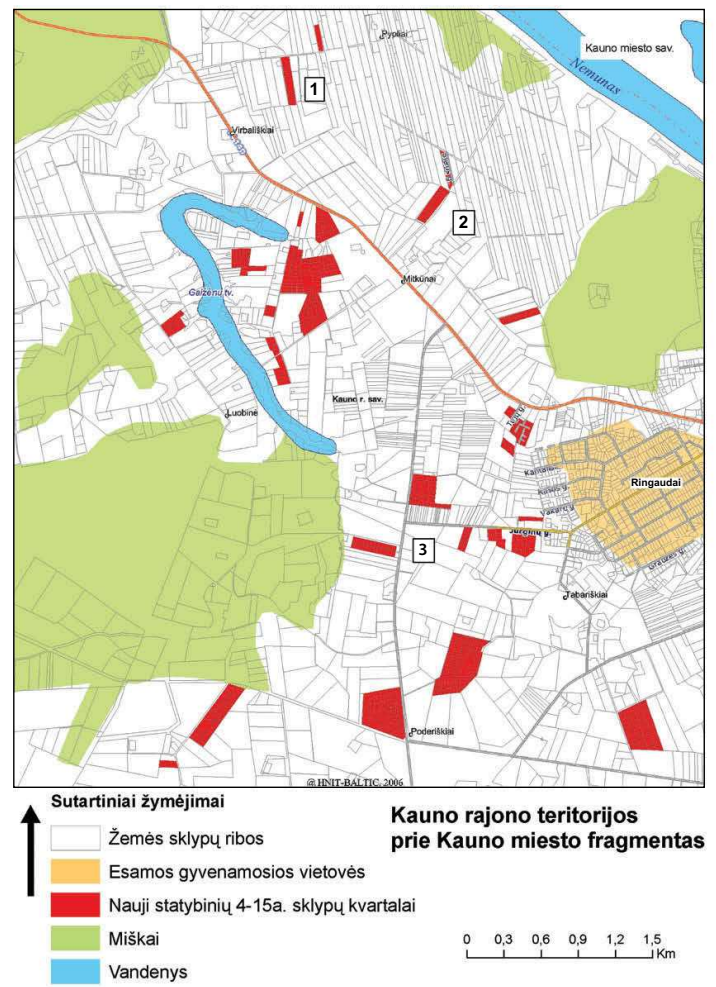

B

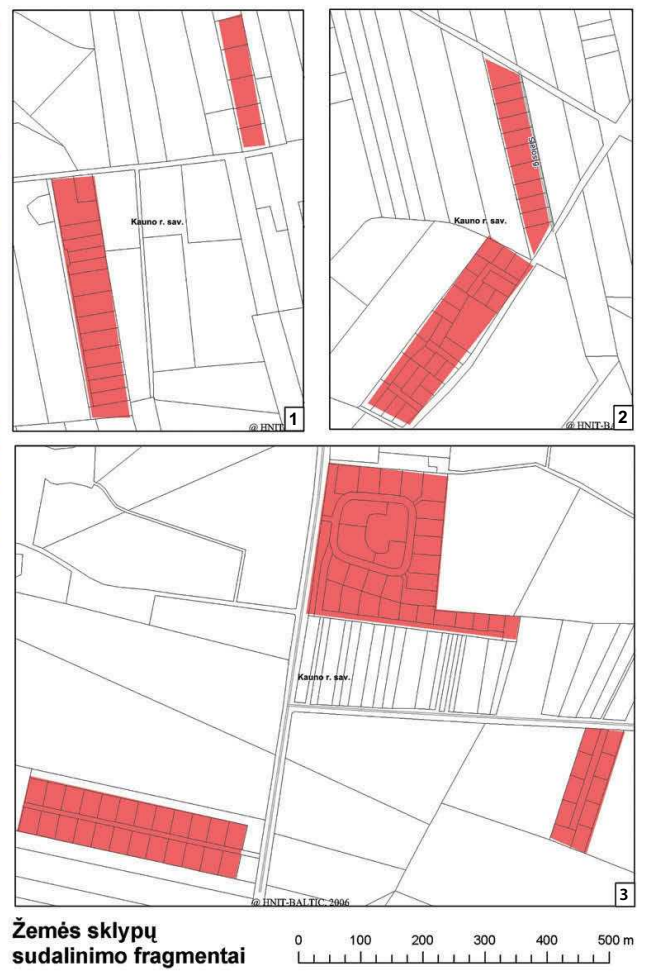

1 pav. Teritorijų urbanistinio vystymo procesas Kauno rajone. Žemès ūkio paskirties teritorijos (balta spalva) specialiaisiais, detaliaisiais planais keičiama i kitos paskirties teritorijas (raudona spalva). Pirminiai žemės sklypai sudalinami mažesniais sklypais sudarant klaidžios struktūros susisiekimo sistemą, padriką gyvenamujjų kvartalų išsidėstymą ( $\mathrm{A}$ - atskirai vystomų žemès sklypų išsidėstymas; $B$ - atskirų žemės sklypų vystymo fragmentai (raudona spalva - gyvenamujų namų sklypai)) (schema sudaryta remiantis Vl Registru centras 2007 m. duomenimis. Topografinis pagrindas: Hnit-Baltic, www.maps.It)

Fig. 1. The process of urban development in Kaunas district. The agricultural land use (white color) are changed to other (urban) land use (red color) by special, detail plans. The former parcels are devided into more small parcels making chaotic structure of roads, overbuilt areas ( $A$ - the layout of separately developed parcels; $\mathrm{B}$ - the fragments of subdivision of individual parcels (red color - the parcels for family housing structures)) (The source: Vl Registrų centras 2007, Hnit-Baltic, www.maps.It)

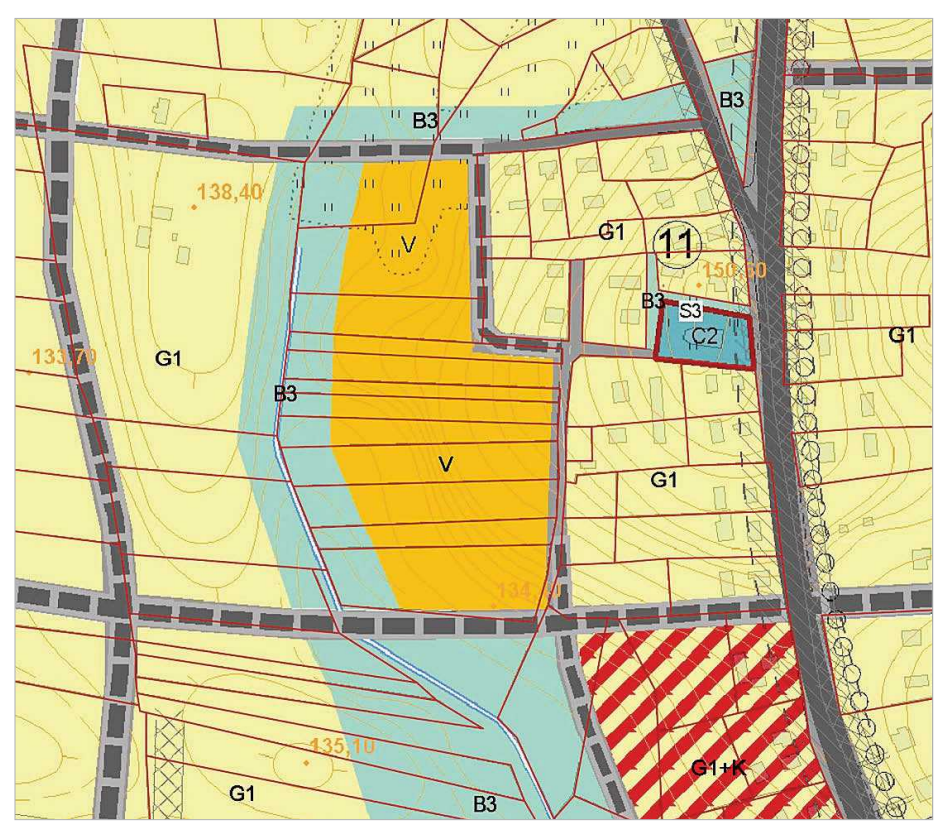

2 pav. Pagal bendrojo plano sprendinius dalis buvusių žemès ūkio paskirties sklypu patenka i gyvenamąsias (G1), dalis i visuomeninès paskirties (V), dalis ị bendro naudojimo (B3) ir kt. teritorijas (ištrauka iš Kelmès miesto teritorijos bendrojo plano 2007)

Fig. 2. According master plans proposals former agricultural parcels appear in territories of new land use: living $(G)$, social (V), public (B3). (Extract from Master plan of Kelme town, KUT Institute of Architecture and Construction 2007) 
teritorijų dalis buvo susiformavusi savaime. Todèl buvo reikalingi gan dideli darbai miestų erdvinei struktūrai atstatyti bei tobulinti.

Siekiant planingai atstatyti sugriautus miestus buvo išleistas „Laikinasis miestų ir miestelių planingam statymui įsakymas" (1920). Šiuo įsakymu buvo apibrèžti bendri miestų statybos principai, pagrindiniai miesto objektai, kurie turèjo būti numatomi, rengiant miestų planus, ir kiti reikalavimai planavimo dokumentams rengti.

Tačiau miestų teritorijai tvarkyti bei plèsti, kaip ir minèta, daug kliūčių sudare privati žemès nuosavybè, kuriai tvarkyti pagal miestų planus nebuvo parengta atskirų teisinių nuostatų. Dẻl esamų gatvių platinimo bei kitų viešųjų erdvių ịkūrimo kildavo ginčų bei teismų (Likas 2001). Dažnai miesto planavimo klausimus tekdavo spręsti naudojant atskirąsias teisines priemones - išleidžiant atskirus teisinius nutarimus, skirtus žemei nusavinti, pavyzdžiui, konkrečioms gatvėms tiesti (Akcinès... 1936), joms išplatinti ir pan. Dèl šių priežasčių daugelis miesto planų tapo neigyvendinami arba jų igyvendinimas turèjo trukti ilgą laikotarpị.

Šias problemas išsprende $1938 \mathrm{~m}$. išleistas „Miestų žemių tvarkymo įstatymas", kuris ypač atitiko Vokietijoje vykdomą žemès pertvarkymą. Pagal įstatymą buvo apibrèžti naujų planų parengimo, statybinių sklypų suformavimo, žemès skyrimo viešosioms rei- kmèms (naujiems keliams, gatvèms tiesti, platinti, naujoms aikštems, skverams, parkams kurti, taip pat kitiems savivaldybių objektams), nuostolių atlyginimo reikalavimai (3 pav.). İstatyme buvo nurodoma, kad žemès sklypai pertvarkomi prisilaikant miesto plano. O viešoji infrastruktūra kuriama imant žemes iš visu žemés savininku proporcingai ju turimos žemés vertei. Viešajai infrastruktūrai buvo numatyta skirti - $30 \%$ ploto nuo kiekvieno žemès sklypo. Dèl sklypo dalies netekimo atsiradę nuostoliai buvo laikomi ekvivalen$t u$ tų žemès sklypų vertès padidejjimui ir atlyginimas už ją nebuvo mokamas. Tuo metu buvo laikoma, kad sklypų verte padidėdavo planavimo sprendiniais numačius naujus patogumus, pagražinus gyvenamąją aplinką. Jei nuostoliai buvo patiriami dèl didesnių nei normose numatytų gatvių parametrų, tai nuostolius padengdavo savivaldybè. Jei iš gatvių turejo naudos ir kitų nepaliestų žemių savininkai, jiems galèjo būti nustatyta prievolè taip pat atlyginti dalị išlaidų, skirtų gatvèms. Apskritai atlyginimas už paimtą žemę buvo diferencijuotas, atsižvelgiant i ž žemès tvarkymu pasiekiamą naudą tiek miestui, tiek savininkams.

Šie žemès pertvarkymo nuostatai rodo, kad jau tarpukario Lietuvoje buvo sudarytos labai aukšto lygio teritorijų planavimo organizacinès priemonès, kurios leido pasiekti kokybišką teritorijų suplanavimą.

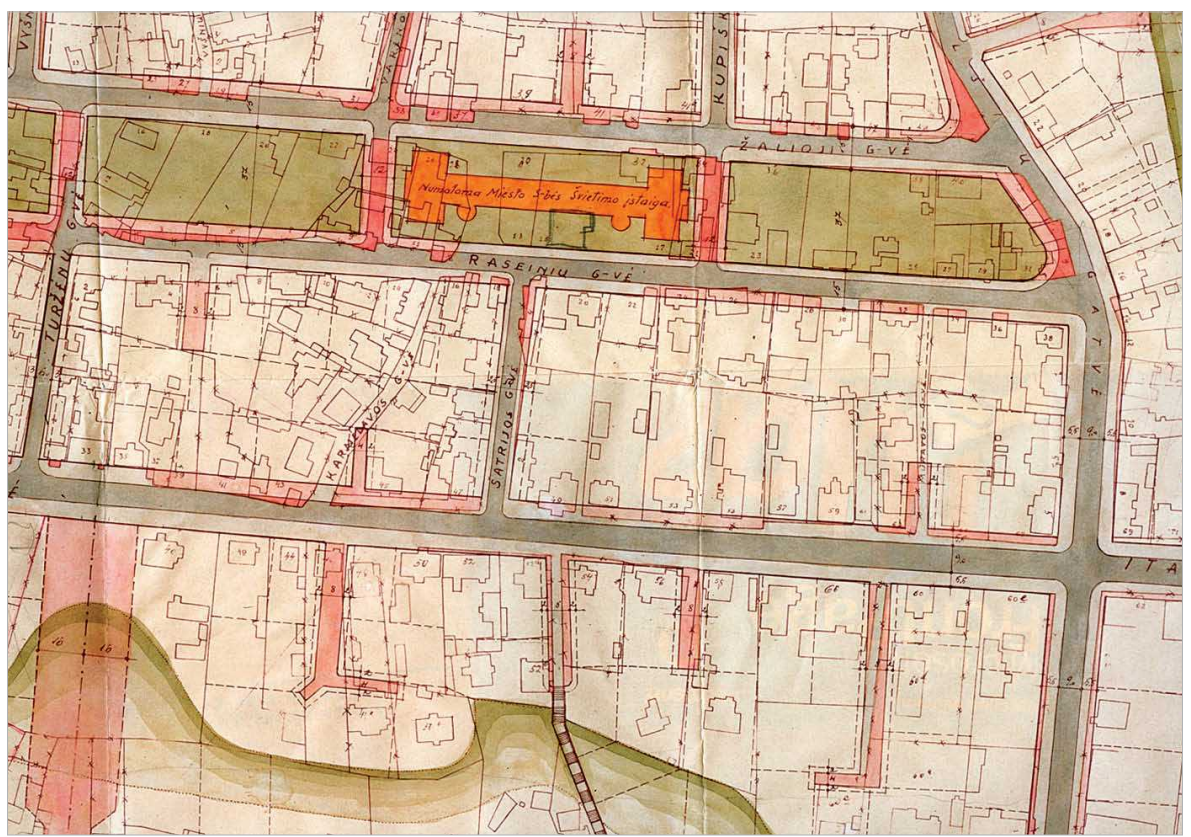

3 pav. Rajono tarp Neries, Ažzuolų g., Savanorių pr. ir Žemaičių g. suplanavimo projektas, 1940 m. (ištrauka). Projektu numatomas esamų gatvių platinimas, naujų tiesimas (raudona sp.), želdynų formavimas (žalia sp.), visuomeninių objektų išdèstymas (oranžinè sp.), žemès sklypų pertvarkymas (KAA, F.218, ap. 4, b.1b)

Fig. 3. The detail plan of area between Neris river, Azuolu str., Savanoriu str., Zemaiciu str. (Kaunas), 1940 (fragment of the plan). It is planned the widening of streets, new streests (red color), green structures (green color), public buildings (orange color), land readjustment. (KAA, F.218, ap. 4, b.1b) 


\section{Užsienio šalių miestų teritorijų planavimas}

\section{Žemess sklypu pertvarkymo tikslai ir metodai planuojant miestus}

İvertinant daugelị praktinių bei analitinių užsienio darbų, galima išskirti, kad nemažai valstybių, siekdamos kokybiško urbanistinio vystymo, yra parengusių specialias teritorijų planavimo priemones, pagristas žemès sklypų pertvarkymu, restruktūrizavimu. Šiomis teritorijų planavimo priemonėmis yra numatomas bei igyvendinamas žemès sklypų perplanavimas, viešo naudojimo teritorijų sukūrimas. Daugelyje užsienio valstybių tokios miestų teritorijų planavimo priemonès yra įtvirtintos įstatymuose kaip žemès pertvarkymo metodas (land readjustment). Jis yra taikomas tiek planuojant naujas dideles miestų teritorijas, tiek modernizuojant esamas atskiras miestų dalis.

Užsienio miestuose taikomas žemès pertvarkymo metodas yra kilęs iš žemès ūkio teritorijų pertvarkymo - konsolidacijos (land consolidation) pavyzdžio. Pati šio žemių pertvarkymo metodo pradžia yra XVIII a., kada po didesnių gaisrų buvo siekiama planingai atstatyti miestus. Pirmieji teisiniai miestu žemès pertvarkymo principai buvo įtvirtinti $1902 \mathrm{~m}$. Vokietijoje, išleidus žemès pertvarkymą reglamentavusị įstatymą Lex Adickes (Muller-Jokel 2004). Vèliau Vokietijos pavyzdžiu paseke ir kitos šalys. Visai ša- liai tvarkyti šį metodą įtvirtino Švedija, Prancūzija, Japonija, Pietų Koreja, Taivanis, Turkija, Indonezija, Suomija ir kt. Kai kuriems miestams vystyti ji perèmé JAV, Kolumbija, Indija, Tailandas, Malaizija, Nepalas, Kanada, Filipinai, Australija ir kt. (4 pav.).

Žemès pertvarkymo metodo esmę sudaro žemès savininkų sutelkimas jungtiniam teritorijų vystymui, tai yra kartu sujungiant valstybès bei privačių savininkų pastangas racionaliam urbanistiniam vystymui. Šiuo metodu yra kartu derinamos savanoriškos ir priverstinès teritorijų planavimo priemonès (t. y. žemès savininko dalyvavimas planavimo procese ir žemès paèmimas visuomenés poreikiams) (Viitanen 2000). Svarbiausi žemės pertvarkymo tikslai yra naujų teritorijų urbanizavimas, teritorijų konversija, stambių kompleksų (infrastruktūros, investicinių objektų) integravimas, urbanistinio išdrikimo stabdymas.

Kaip vieną iš efektyviausių žemės pertvarkymo metodą taikančių valstybių iki šiol išskiriama Vokietija (Larson 1997; Sonnenberg 1996). Šioje šalyje žemès sklypų pertvarkymo efektyvumas siejamas su galimybèmis operatyviai organizuoti planavimo darbus, taupant laiką ir lěšų sąnaudas. Pati žemès pertvarkymo procedūra čia yra pagrịsta iš anksto parengto detaliojo plano praktiniu realizavimu ir gaunamos naudos padalinimu tarp žemès savininkų bei savivaldybès. Tokia procedūra taip pat numatyta Suomijoje, Turkijoje (Turk 2001).
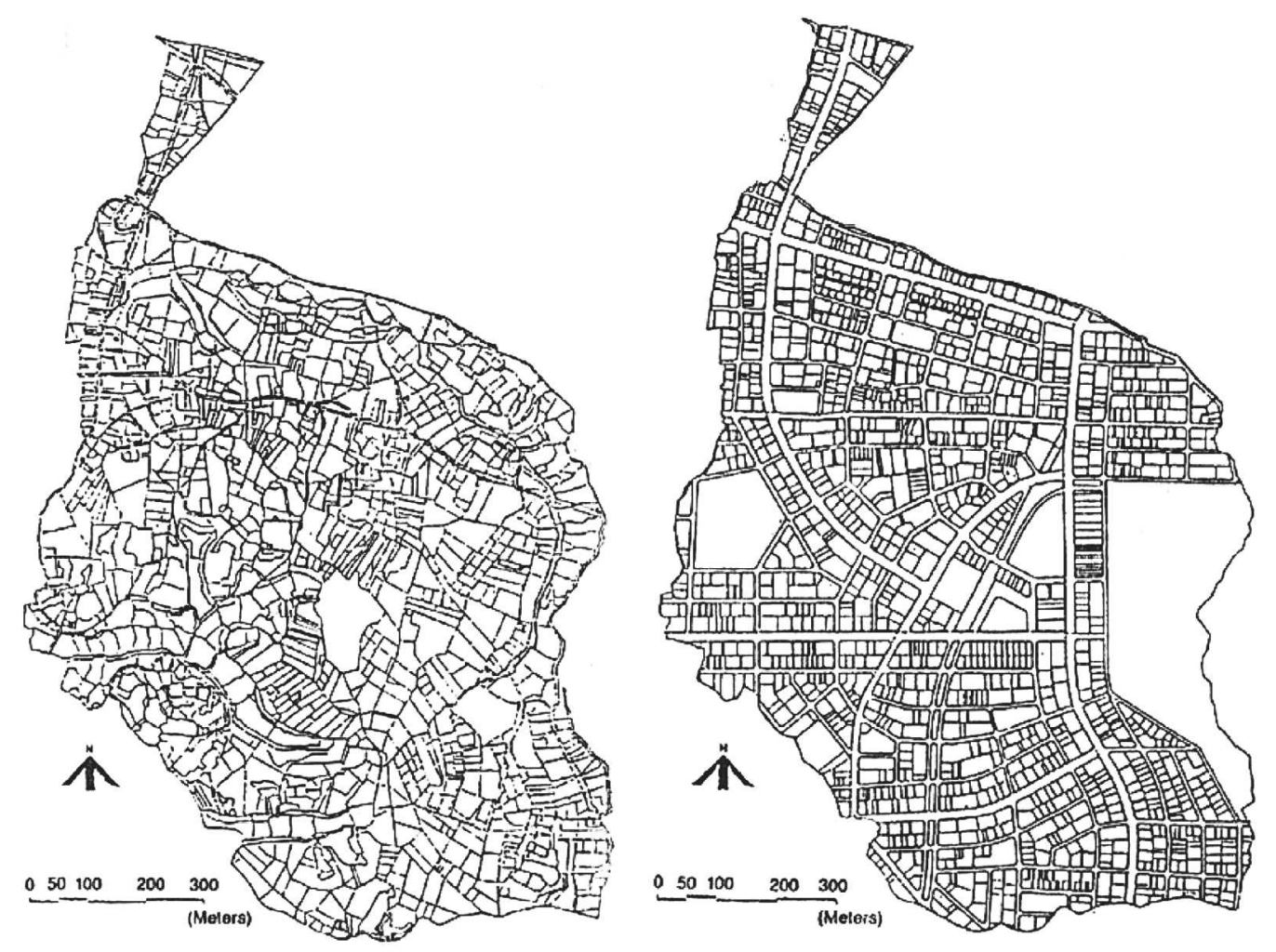

4 pav. Žemès pertvarkymo pavyzdys Japonijoje (Larson 1993)

Fig. 4. Example of land readjustment in Japan (Larson 1993) 
Kitose valstybėse teritorijos detaliojo planavimo ir žemés pertvarkymo plano procedūros rengiamos vienu metu. Taip sudaromos galimybės vienai procedūrai veikti kitą, tačiau kartu sudaromos prielaidos joms labai išsitęsti, pavyzdžiui, Švedijoje.

Dar kitose valstybėse detaliojo planavimo ir žemès pertvarkymo planai yra rengiami kaip viena procedūra apskritai. Tačiau taikant šį žemès pertvarkymo būdą atsiranda prielaidų ne tik procesui išsitęsti, bet taip pat pakenti ir urbanistinei kokybei. Vienu metu rengiant detalųji ir žemès pertvarkymo planą, susidaro sąlygos žemės pertvarkymo interesams tapti aukštesniems už urbanistinius sprendinius (Japonija, Prancūzija).

Taip pat reikia pastebèti, kad daugelis valstybių dar nèra iki galo ịtvirtinusios visų procedūrinių nuostatų - jose šio metodo taikymas tobulinamas (Suomija, Turkija, Kolumbija ir kt.). Todèl žemès pertvarkymo sistemos principai ir pagrindai toliau pateikiami remiantis jau minètos Vokietijos patirtimi.

\section{Miestųžemés sklypų pertvarkymo patirtis Vokietijoje}

Vokietijoje žemė pertvarkoma (vok. Umlegung) remiantis parengtais planavimo dokumentais - parengiamuoju ir teisiniu žemès naudojimo planu (Lietuvoje jie atitinka bendrąjį ir detalųji planą).

Žemess pertvarkymo plano rengimą, visus svarstymus ir derybas su žemès savininkais, patenkančiais $\mathfrak{i}$ pertvarkomą teritoriją, organizuoja vietos savivaldybès administracija. Tačiau atsakomybė už visus pertvarkymo projekto sprendimus tenka nepriklausomai žemès pertvarkymo tarybai, įsteigtai savivaldybių. Šią tarybą paprastai sudaro penki asmenys: teisèjas, žemès vertintojas, žemès kontrolierius ir du asmenys iš vietos tarybos. Ši procedūra rengiama vadovaujantis teisiniu žemès naudojimo planu (detaliuoju planu). Tačiau ji taip pat gali būti pradèta, net jei nèra patvirtinto teisinio žemès naudojimo plano, - ji galima patvirtinti tuo pačiu metu kaip ir žemès pertvarkymo projektą. Gyventojai i šš žemès pertvarkymo procesą įtraukiami nuo proceso pradžios: ịvertinami jų norai, svarstomos galimybès, apribojimai, pristatoma koncepcija, aptariami sprendiniai su kiekvienu asmeniškai.

Praktikoje žemės pertvarkymo planai rengiami didelèms, didesnèms nei 100 ha ploto, ir taip pat mažoms, mažesnems nei 1 ha ploto, teritorijoms. Pertvarkant žemę, pirmiausiai, atskiri žemès sklypai planuojamoje teritorijoje tariamai sujungiami, konsoliduojami ị vieną sklypą (pertvarkymo masę), kuriame bendri savininkai turi tam tikrą savo dali priklausomai nuo turèto ploto ar priklausomai nuo turètos žemės sklypo vertès. Iš tokio konsoliduoto sklypo atskiriama žemès dalis, reikalinga viešosioms teritorijoms, ir perduodama savivaldybėms. Vokietijoje pertvarkant žemę visuome- nès poreikiams naujai vystomose teritorijose paimama $30 \%$, o pertvarkant esamas miesto dalis $-10 \%$ ploto nuo kiekvieno žemès sklypo (Baugesetsbuch 1990). Likusi konsoliduoto sklypo dalis (paskirstymo masė) paskirstoma žemès savininkams. Iš jos kiekvienas gauna savo dalị, atitinkančią santykinę vertę, buvusią prieš pradedant žemès pertvarkymo procedūrą. Naujos žemès sklypų ribos suformuojamos pagal teisinio žemès naudojimo plano (detaliojo plano) sprendinius.

Remiantis Vokietijos pavyzdžiu, galima išskirti du žemès pertvarkymo būdus, leidžiančius užtikrinti vienodą žemès sklypų verčių santykị, tai: a) žemès pertvarkymas įvertinant santykinį žemès sklypų ploto pokytị ar b) žemès pertvarkymas įvertinant santykini žemės sklypu vertès pokytị.

Pirmasis būdas, leidžiantis užtikrinti tą pati žemès sklypų vertès santykį, yra iš esmès jau anksčiau minètas proporcingas žemès sklypu ploto kitimas, kuris siejamas su visuomenès poreikiams reikalingu teritoriju formavimu. Šis būdas taikomas, jei pirminiai ir naujai paskirstomi žemės sklypai yra tolygios vertès (pavyzdžiui, prieš planavimą visi yra žemès ūkio paskirties, o planuojami nauji sklypai visi yra gyvenamosios teritorijos ar pan.).

Antrasis būdas yra žemès sklypų pertvarkymas priklausomai nuo esamos ir naujai sukuriamos ju vertès kitimo. Šis būdas taikomas, jei žemės sklypai prieš pradedant žemès pertvarkymą buvo nevienodos vertès (pavyzdžiui, dalis sklypų užstatyti, o dalis sklypų ne). Taip pat šis būdas taikomas, siekiant urbanistiniu planavimu tiksliau padalinti gaunamą naudą tarp savininkų ir savivaldybès. Žemès savininkai gauna naudą dèl to, kad paruošus parengiamąji planą (bendrąji planą) padidèja žemès vertè, iš žemès ūkio paskirties ji tampa potencialaus vystymo teritorija. Savivaldybei nauda tenka iš žemès vertès padidejimo skirtumo, susidarančio parengus teisinį žemès naudojimo planą (detalųji planą) ir žemès pertvarkymo planą, tai yra iš žemès vertès skirtumo tarp potencialaus vystymo teritorijos ir statybinès žemès (5 pav.).

Skirstant naujus žemès sklypus iš perskirstymo masès kiekvienas žemès savininkas gauna žemès sklypą, kurio rinkos vertè yra ne mažesnè nei buvo prieš pertvarkymą. Nauji žemès sklypai išdèstomi tose pačiose ar artimose vietose, kuriose jie buvo prieš pradedant rengti žemès pertvarkymo projektą. Taip pat Vokietijoje žemès savininkas, jei jis sutinka, gali igyti bendros nuosavybès sklypą ar žemès sklypą už žemès pertvarkymo teritorijos ribų.

Galutinai žemės pertvarkymo plane nurodomos esamos ir būsimos sklypų vertès, jų išdèstymas, suplanavimas, sudalinimas, neužstatomos aplinkosauginès, kraštovaizdžio teritorijos, už jas mokamos kompensacijos ir kt. Visos žemès pertvarkymo procedūrinès 


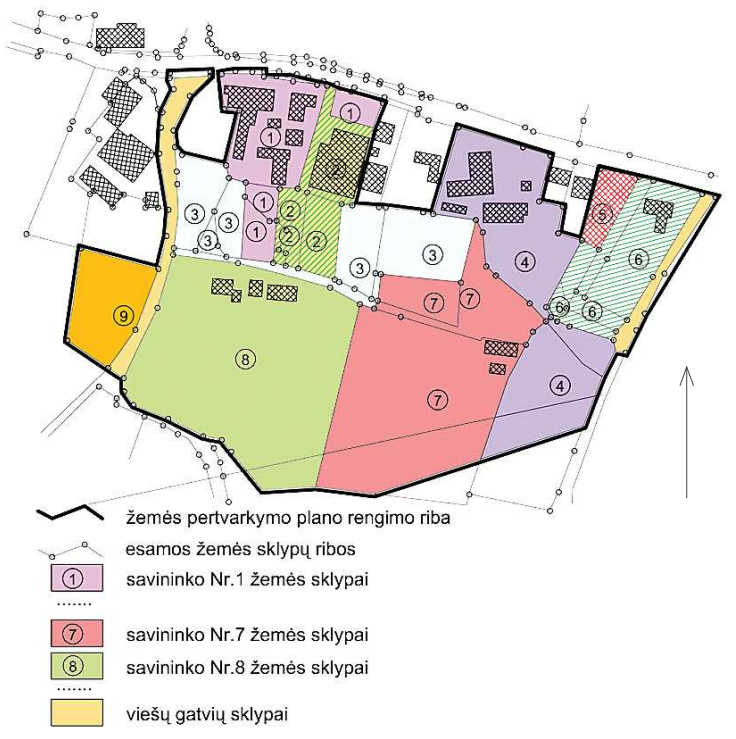

A - žemès nuosavybès planas

A - Land ownership plan

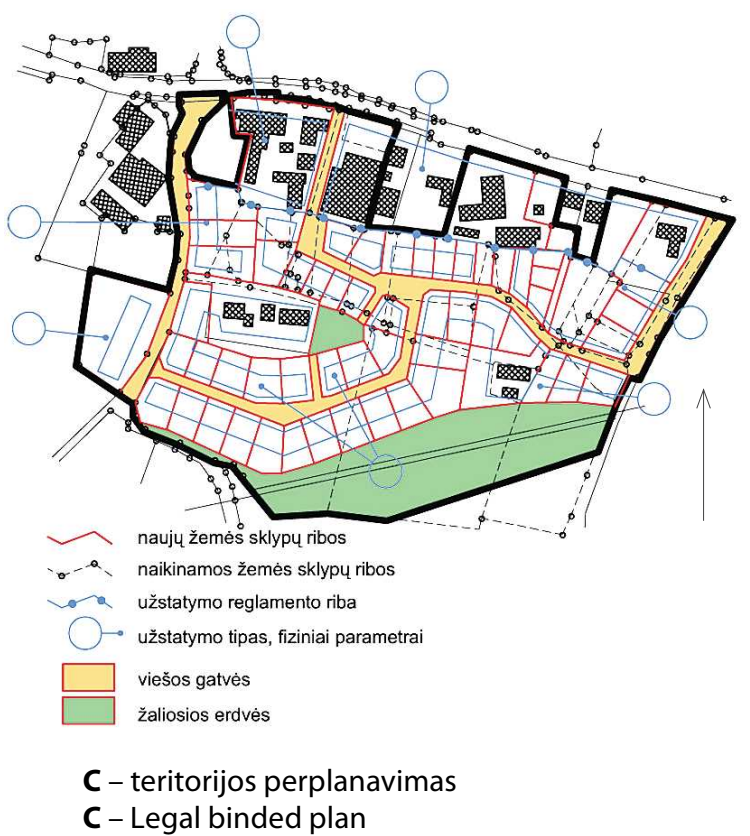

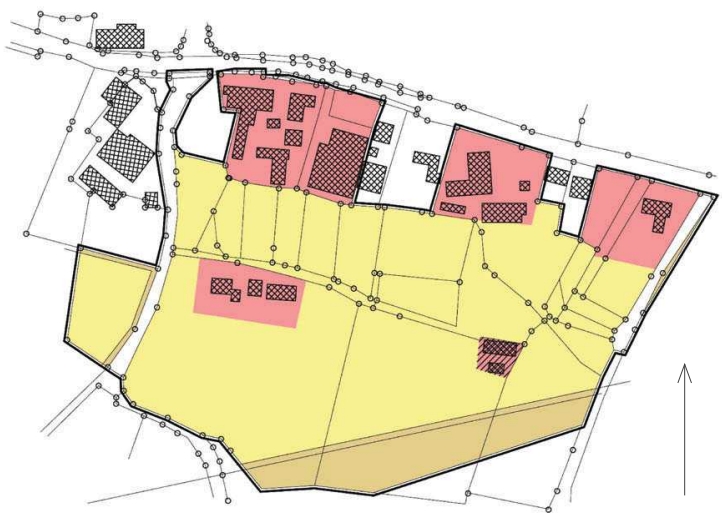

$85-\mathrm{DM} / \mathrm{m}^{2}$ neišvystyta žemè

$135-\mathrm{DM} / \mathrm{m}^{2}$ užstatyta žemé

$7-\mathrm{DM} / \mathrm{m}^{2}$ aplinkosauginiai žemés naudojimo apribojimai

$126,50-\mathrm{DM} / \mathrm{m}^{2}$ užstatyta žemé (su naudojimo prievolèmis)

B - žemès vertinimas

B - Land evaluation plan

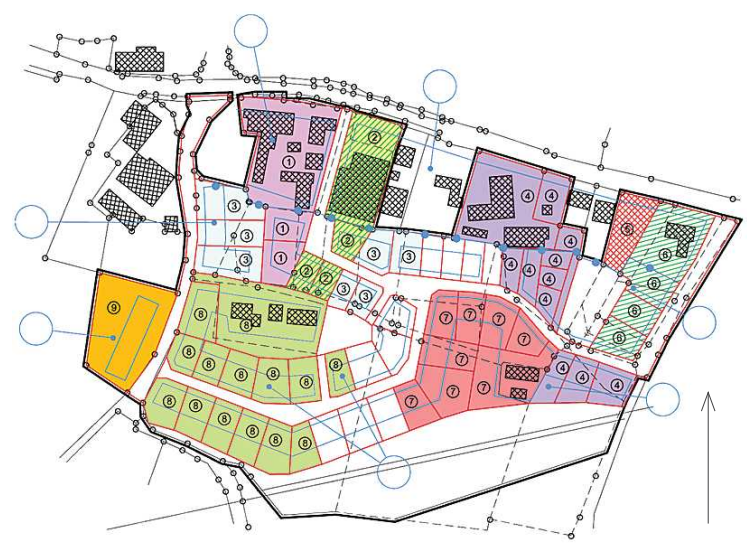

Naujai suformuotu žemès sklypu nuosavybè

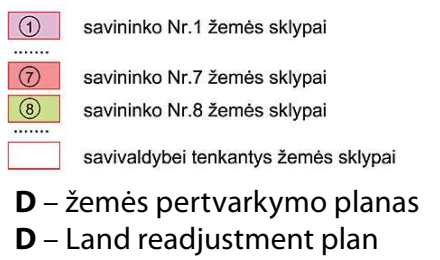

5 pav. Žemės pertvarkymo (Umlegung) projekto rengimo pavyzdys Vokietijoje (Meindl 2002)

Fig. 5. Example of land readjustment („Umlegung“) procedure in Germany (Meindl 2002)

išlaidos tenka savivaldybei, žemès savininkams nereikia mokèti notarinių, geodezinių matavimo, kadastro išlaidų (remiantis Muller-Jokel 2004).

\section{Žemès pertvarkymo metodo privalumai ir šalies miestų teritorijų planavimo tobulinimo galimybès}

Žemès pertvarkymo metodu planuojant bei vystant teritorijas, pirmiausiai yra sudaromos galimybès siekti urbanistinès kokybès: racionaliai suformuoti statybinius sklypus, išdèstyti atitinkamas teritorijos naudo- jimo funkcijas joms tinkamiausiose vietose. Taip pat šiuo žemès pertvarkymo metodu yra laimima tokių privalumų kaip: a) užtikrinamas susidarančių išlaidų padengimas; b) žemés paèmimo visuomenès poreikiams procedūra tampa daug aiškesnè ir teisingesné; c) išlaikomas žemės savininkų turètų sklypų verčių santykis.

Išlaidos, susidarančios pertvarkant žemès sklypus, yra padengiamos tuo metu gaunama nauda. Paprastai kiekviena valstybė numato, ar susidarančios išlaidos yra dengiamos savivaldybių, ar savininkų, ar bendrai 
abiejų pusių. Šiuo metodu yra užtikrinama savivaldybès teisè ị dalị pelno, gaunamo atlikus pertvarkymo procedūrą. Gaunamas savivaldybės pelnas siejamas su išlaidų padengimu pertvarkymo procedūrai atlikti, inžineriniam teritorijų aprūpinimui ar kt. Tokị gaunamą savivaldybių pelną gali sudaryti tiek pinigine išraiška gaunamos priemokos, tiek žemès dalis, gaunama pagal urbanistinių normų reikalavimus ar pagal atskirus susitarimus su žemès savininkais.

Žemès pertvarkymo metodu sudaromos sąlygos visiems žemès savininkams vienodai prisidèti prie bendro naudojimo, visuomeninių teritorijų sukūrimo. Tai yra sudaromos sąlygos visuomenès poreikiams atskirti santykinai vienodą dalį nuo visų sklypų. Pertvarkant vienu metu visus žemès sklypus, nereikalinga taikyti tradicinès žemès paèmimo visuomenès poreikiams procedūros, kuri paprastai taikoma atskiriems žemès sklypams nusavinti. Be minetos Vokietijos, kitose šalyse, pavyzdžiui, kaip Japonija, visuomenès poreikiams bendrai paimama $30 \%$, Pietų Korejoje $50 \%$ ir daugiau, Taivanyje, Turkijoje $40 \%$ teritorijos nuo kiekvieno žemes sklypo (Larson 1997; Sorensen 2000; Konursay 2004).

Teritorijos planavimas, pertvarkant žemès sklypus, taip pat leidžia išlaikyti žemės sklypų verčių santykį. Visiems žemės sklypams vienu metu taikomi vienodi vertinimo kriterijai, kuriais užtikrinamas vienodas sklypų vertės pokytis. Vienodo žemès sklypų vertès pokyčio pasiekti vykdant ịprastą, šiuo metu taikomą Lietuvoje teritorijų planavimo procedūrą yra sunku, vienų savininkų žemès sklypų vertẻ labai pakyla, o kitų ne. I planavimo procesą ịtraukus žemès pertvarkymo procedūrą, sudaromos priemonès išlaikyti tą patị turètų žemès sklypų vertès santykị, koks buvo prieš įvykdant žemès pertvarkymo darbus ir juos įvykdžius.

Šiuo metu Lietuvoje žemès sklypų struktūra suformuota iš esmès neįvertinant miestų plètimosi, viešųju erdvių rezervavimo, aplinkos kokybès gerinimo perspektyvų. Todèl užsienio šalyse naudojamo žemès pertvarkymo metodo pritaikymas mūsų šalyje galètų būti vienas iš efektyviausių būdų, siekiant išspręsti daugelị šiuo metu kylančių teritorijų planavimo problemų.

Teritorijų planavimo procesui tobulinti priemonès jau yra rengiamos. Vienos jų - jau minèti naujos redakcijos „Teritorijų planavimo įstatymo projektas“ (2010), „Miestų, miestelių ir kaimų (gyvenamųjų vietovių) planavimo normų projektas" (2008). Juose nurodoma, kad urbanistiniai teritorijų planai (užstatymo planai) turi būti rengiami kompleksiškai vientisai urbanistinei teritorijai, o žemès sklypai pertvarkomi atskirais žemèvaldų projektais. Šie teisiniai dokumentai iš esmès turètų sudaryti prielaidas pagristam urbanizuotų teritorijų vystymui, viešųjų bei statybinių teritorijų kūri- mui. Tačiau praktiniam jų realizavimui dar reikalingas aiškus miestų žemès sklypų pertvarkymo mechanizmas, nuostoliu atlyginimo pagrindimas.

Šalies miestų žemès sklypų pertvarkymui reglamentuoti turètų būti parengtas atskiras teisinis dokumentas. Kaip pagrindas jam galètų būti anksčiau pateiktas vienas efektyviausių Vokietijoje naudojamų žemès pertvarkymo metodų, kuris kartu buvo realizuotas ir tarpukario Lietuvoje. Ivertinant šio žemès pertvarkymo metodo organizavimo, rengimo bei derinimo principus, šalies miestų žemės sklypų pertvarkymą reglamentuojančio teisinio dokumento nuostatai galettų būti parengti remiantis toliau pateikiamais koncepciniais aspektais.

\section{Žemés sklypu pertvarkymo plano rengimo organizavimas}

- žemès sklypų pertvarkymo projektas rengiamas vientisam urbanizuojamos teritorijos plotui;

- žemès sklypu pertvarkymas organizuojamas pagal esamą patvirtintą vientisos teritorijos detalųji planą (ar bendrąji planą), parengtą vietos savivaldybès;

- žemès skypų pertvarkymą organizuoja speciali vyriausybès, savivaldybès ịsteigta institucija (pavyzdžiui, žemès pertvarkymo departamentas, komisija, sudaryta iš ekspertų ar pan.);

- žemès sklypų pertvarkymą gali inicijuoti vyriausybė, taip pat savivaldybès atskiru nutarimu ar gavusios žemès savininkų prašymus;

- vykdant žemés sklypų pertvarkymo darbus, turi būti atsižvelgta ị žemès savininkų, valdytojų, trečiųjų asmenų, visuomenès interesus.

\section{Žemés sklypu pertvarkymo kriterijai}

- Žemès sklypai pertvarkomi priklausomai nuo pertvarkomos teritorijos erdvinès struktūros pobūdžio dviem būdais: 1) žemé pertvarkoma pagal plotą ar 2) pagal vertę;

- pertvarkant žemės sklypus pagal plotą, naujai vystomose teritorijose skiriama $30 \%$ ploto nuo kiekvieno sklypo viešajai infrastruktūrai įrengti bei savivaldybès reikmėms. Modernizuojant esamas užstatytas teritorijas, kuriose susisiekimo infrastruktūra, želdynų sistema yra susiklosčiusios, viešajai infrastruktūrai išplèsti ar naujiems savivaldybès objektams skiriama po $10 \%$ ploto nuo kiekvieno sklypo (patvirtinus „Miestų, miestelių ir kaimų (gyvenamųjų vietovių) planavimo normas“, viešosioms teritorijoms žemè turètų būti skiriama pagal normose nurodytus dydžius, bet ne mažiau, nei nurodyta anksčiau);

- atlyginimas už paimamą normomis nustatytą žemès sklypo dalị laikomas adekvačiu planuojant sukuriamai teritorijos vertei; 
- nuostolius, susidarančius dèl didesnio, nei nurodyta normose, žemès ploto paėmimo visuomenès poreikiams, atlygina savivaldybès;

- savivaldybès turi teisę i naudą, gaunamą pertvarkant žemę, kurią gali pasiimti žemės sklypais;

- vykdant žemès sklypų pertvarkymo darbus, turi būti užtikrinamas tas pats žemès sklypų vertès santykis, koks buvo prieš pertvarkant žemès sklypus ir pertvarkius juos.

\section{Išvados}

1. Šiuo metu Lietuvos teritorijų planavimo ir žemès tvarkymo ìstatymų bazès sisteminiai trūkumai neleidžia visiškai užtikrinti urbanistinès, gyvenamosios aplinkos kokybès gerinimo. Dèl to sunku sukurti kokybiškas statybinių bei neužstatomų sklypų, gatvių tinklo ir kt. struktūras, užtikrinti reikiamą viešųjų teritorijų, tokių kaip želdynų, atvirų erdvių, gatvių ir kt. plotą.

2. Daugelyje užsienio šalių, siekiant kokybiško miesto teritorijų urbanistinio suplanavimo privačios nuosavybès sąlygomis, žemè yra pertvarkoma. Pertvarkant žemę sujungiamos savanoriškos bei priverstinès teritorijų planavimo priemonès, kurios leidžia ị teritorijų planavimą įsitraukti savininkams ir kartu užtikrinti visuomenès interesą.

3. Viena iš efektyviausių ir paprasčiausių miesto žemès pertvarkymo procedūrų yra pagrịsta žemés sklypu pertvarkymu pagal teritorijų planavimo sprendinius. Žemès sklypų pertvarkymas pagal teritorijų planavimo sprendinius taikomas Vokietijoje, Suomijoje, Turkijoje. Iš jų kaip seniausiai taikančią šį žemès pertvarkymo metodą ir labiausiai patyrusią galima išskirti Vokietiją. Kitose šalyse žemès pertvarkymas yra ne toks efektyvus, vertinant sunaudojamo laiko ar pasiekiamos kokybès požiūriu (Švedija, Prancūzija, Japonija, Vakarų Australija, kt.).

4. Siekiant miesto teritorijų planavimo efektyvumo padidinimo, teisingumo tarp žemès savininkų, urbanistinio planavimo kokybès pagerinimo, lèšu sutaupymo bei bendrai kokybiškesnès gyvenamosios aplinkos sukūrimo, yra būtinas žemès sklypu pertvarkymo priemonių, papildančių dabartinius šalies teritorijų planavimo teisinius dokumentus, parengimas.

5. Parengus miestų žemès sklypų pertvarkymą reglamentuojančius teisinius dokumentus būtų sudarytos priemonès, skirtos: a) teritorijų planavimo išlaidoms padengti; b) aiškesnei žemès paėmimo visuomenès poreikiams procedūrai sudaryti; c) teisingumui užtikrinti tarp visų žemès savininkų.

\section{Literatūra}

Aleknavičius, P. 2002. Ar reguliuosime žemès ūkio paskirties žemès rinką?, Žemès ūkis 1: 5-7.

Akcinès bendrovès „Mechanikas“ ̌̌emei Panevėžio miesto gatvèms nusavinti įstatymas, Vyriausybès žinios, 1936. Nr. 524/3639.

Bardauskiene, D. 2007. Miesto bendrasis planas ir ekspertiniai vertinimai, Urbanistika ir architektūra [Town Planning and Architecture] 31(3): 119-130.

Burinskienè, M. 2003. Subalansuota miestu pletra. Vilnius: Technika.

Darnioji plètra teritorijų planavime ir urbanistikoje. 2008. Vilnius: Lietuvos nekilnojamojo turto pletros asociacija.

Daunora, Z. J. 2001. Miesto gyvenamoji teritorija. Planavimo reglamentavimo metmenys, Urbanistika ir architektūra [Town Planning and Architecture] 25(2): 71-79.

Dringelis, L. 2003. Žemès privatizavimas ir miestų viešojo naudojimo zonų urbanistinis formavimas, Urbanistika ir architektūra [Town Planning and Architecture] 27(4): 163-169.

Federal Building Code (Baugesetzbuch, BauGB). 1990 [interaktyvus]. Federal Ministry for Transport, Construction and Housing, Germany [žiūrèta 2009 m. kovo 19 d.]. Prieiga per internetą: $<$ http://www.iuscomp.org/gla/statutes/BauGB.htm>.

Gil, S. Planning Regulations \& Tools Applied in France [interaktyvus]. Athens Workshop (Informal Settlements), 28-31 March 2007 [žiūrèta $2011 \mathrm{~m}$. rugpjūčio 19 d.]. Prieiga per internetą: <http://library.tee.gr/digital/m2267/m2267_gil.pdf>.

Juškevičius, P.; Bardauskienè, D.; Pakalnis, M.; Staniūnas, E.; Šulcienè, I. 2008. Darnioji plètra teritoriju planavime ir urbanistikoje. Vilnius: Lietuvos nekilnojamojo turto plètros asociacija.

Kelmés miesto teritorijos bendrasis planas. 2007. KTU Architektūros ir statybos institutas.

Konursay, S. Y. 2004. Land Readjustment Process in Urban Design: Project Management Approach [interaktyvus]. Izmir Institute of Technology Izmir, Turkey 2004 [žiūrèta $2011 \mathrm{~m}$. rugsejo 19 d.]. Prieiga per internetą: $<$ http://library.iyte.edu. tr/tezler/master/sehirplanlama/T000302.pdf $>$.

Laikinasis miestų ir miestelių planingam statymui įsakymas, Laikinosios Vyriausybès žinios 1920, Nr. 20/259.

Land Use and Building Act. NB: unofficial translation 1999 [interaktyvus], [žiūrèta $2008 \mathrm{~m}$. gruodžio 19 d.]. Prieiga per internetą: <http://www.finlex.fi/fi/laki/kaannokset/1999/ en19990132.pdf>.

Larsson, G. 1993. Land Readjustment: A Modern Approach to Urbanization. Avebury, Aldershot, England.

Larsson, G. 1997. Land readjustment: A tool for urban development Original Research Article, Habitat International 21(2): 141-152. doi:10.1016/S0197-3975(96)00059-8

Lietuvos Respublikos vyriausybės nutarimas dèl naujos redakcijos Lietuvos Respublikos Teritorijų planavimo įstatymo koncepcijos, Valstybés žinios, 2010-04-24, Nr. 47-2248.

Lietuvos Respublikos teritorijų planavimo ịstatymas, Valstybès žinios, 1995, Nr. 107-2391.

Lietuvos Respublikos žemès ịstatymas, Valstybès žinios, 2011, Nr. 49-2369.

Likas, G. 2001. 1918-1940 metų Lietuvos statybos įstatymai bei normos, Urbanistika ir architektūra [Town Planning and Architecture] 25(1): 11-26. 
Meindl, R. 2002. Germany Land Reallocation in Cities on the basis of the German Federal building Code, in International Conference 08.11.2002 Nicosia, Cyprus [interaktyvus], [žiūrèta $2011 \mathrm{~m}$. rugpjūčio $19 \mathrm{~d}$.]. Prieiga per internetą: <http:// www.landentwicklung-muenchen.de/mitarbeit/meindl/ veroeffentlichungen/umlegung_vortrag_zypern.pdf $>$.

Miestų žemių tvarkymo įstatymas, Vyriausybès žinios, 1938, Nr. 614/4330.

Miestų ir miestelių teritorijų bendrųjų planų rengimo taisyklès, Valstybès žinios, 2006, Nr. 145-5559

Miestu, miesteliu ir kaimu (gyvenamuju vietoviu) planavimo normos [interaktyvus]. Projektas. 2009. St Vilniaus planas (projekto vadovas M. Pakalnis), [žiūrèta $2011 \mathrm{~m}$. rugpjūčio 19 d.]. Prieiga per internetą: <http://www.am.lt/VI/files/0.456798001240561714.pdf>.

Muller-Jokel, R. 2004. Land Readjustment - A Win-WinStrategy for Sustainable Urban Development [interaktyvus]. Intercontinental Athenaeum Athens, Athens, Greece, May 22 27,2004 [žiūrèta 2011 m. rugpjūčio 19 d.]. Prieiga per internetą: <https://www.fig.net/pub/athens/programme.htm>.

Rajono tarp Neries, Ažzuolų g., Savanoriu pr. ir Žemaičių g. išplanavimo projektas. 1940. KAA, F.218, ap. 4, b.1b.

Ramanauskas, E. 2006. Žemès tvarkymo įstatymų bazé tarpukario Lietuvoje, Urbanistika ir architektūra [Town Planning and Architecture] 30(4): 119-224.

Ramanauskas, E. 2009. Teisinė žemès nuosavybès reikšmė teritorijų planavimui, Urbanistika ir architektūra [Town Planning and Architecture] 33(2): 82-91.

Sonnenberg, J. 1996. The European dimensions and land management - Policy issues (Land readjustment and land consolidation as tools for development), in FIG Commission 7, Annual Meeting 1996, Budapest, Hungary. One Day International Conference, 18 June 1996 „Land Management in the Process of Transition" [interaktyvus], [žiūrèta $2009 \mathrm{~m}$. kovo 19 d.]. Prieiga per internetą: <http:// www.fig.net/commission7/reports/events/bud96/bud961. htm>.

Sorensen, A. 2000. Land readjustment and metropolitan growth: an examination of suburban land development and urban sprawl in the Tokyo metropolitan area, Progress in Planning 53: 217-330. [interaktyvus], [žiūrèta $2011 \mathrm{~m}$. rugpjūčio 19 d.]. Prieiga per internetą: $<$ http://www.utsc.utoronto.ca/ sorensen/ Publications_files/SorensenPIPmonograph.pdf $>$. doi:10.1016/S0305-9006(00)00002-7

Staniūnas, E. 2008. Kraštovaizdžio formavimo teisinè bazė ir aplinkos formavimo praktika, Urbanistika ir architektūra [Town Planning and Architecture] 32 (3): 193-199. doi:10.3846/1392-1630.2008.32.193-199

Turk, S. S. 2002. Land Development and Realization of Local Physical Plans in Urban Areas in Turkey: A Model, in FIGXXII International Congress, April 2002, Washington [interaktyvus], [žiūrèta $2011 \mathrm{~m}$. rugsèjo 18 d.]. Prieiga per internetą: <http://www.fig.net/pub/fig_2002/Ts8-1/TS8_1_ turk.pdf $>$.

Viitanen, K. The Finnish Urban Land Readjustment Procedure in an International Context [interaktyvus]. International Federation of Surveyors [žiūrèta $2011 \mathrm{~m}$. rugpjūčio 19 d.]. Prieiga per internetą: <http://www.fig.net/pub/proceedings/korea/full-papers/pdf/session20/viitanen.pdf $>$.

\section{THE EXPERIENCE OF LAND READJUSTMENT IN URBAN PLANNING}

\section{E. Ramanauskas, L. Dringelis}

Abstract. Nowadays, urban process competes with chaotic structure of land parcels that are not suitable for urban development. Land parcels are of various shapes that usually cannot be developed for building purposes. The structure of parcels is rearranged by planning documents - master and detailed plans. Master plans determine new land use of parcels. These planning documents are used to situate certain group of land parcels in an area of potential development, while other groups - in an area of restrictions or an area that is reserved for the public purposes. In this case, numerous problems occure. At first, the value of one group of parcels increases, meanwhile the value of other group of parcels decreases. Besides the expropriation of territories for the public purposes are carried out only in exceptional cases.

Furthermore, many problems appear when urban territories are developed in very small plots by detailed planning. A suitable composition of parcels cannot be arranged for construction of residential houses. Besides, it is imposable to join all land owners for a common planning action in order to create territories of public use.

In order to resolve such issues, the experience of mid-war Lithuania is described, as well as the know-how of foreign countries. Analysis of land readjustment process in mid-war Lithuania and other countries is carried out. A wider analysis of Germany as one of the most progressive countries in this field is presented.

Keywords: territorial planning, urban development, land readjustment, public interest, legal basis.

\section{EVALDAS RAMANAUSKAS}

Doctor of Humanities (2011) (Arch.); Junior Researcher of the Centre for Territory planning, Kaunas University of Technology, Institute of Architecture and Construction. Tunelio g. 60, 44405 Kaunas, Lithuania.E-mail: krastotvarka@asi.lt

Main research areas: effectiveness of planning documents, rational use of land resources, public areas, town and country landscape.

\section{LIUCIJUS DRINGELIS}

Doctor of Humanities (1983) (Arch.); Head of Centre for Territory Planning, Kaunas University of Technology, Institute of Architecture and Construction. Tunelio g. 60, 44405 Kaunas, Lithuania.E-mail: krastotvarka@asi.lt

Main research areas: landscape architecture and planning of health resorts, planning of recreational and green areas, urban planning, land-use management, cultural heritage.

Research interests: urban nuances of town spatial expansion beyond the old town's borders. Conferences: reports at 5 international and 7 national conferences. Publications: author of monographs and research papers. Teaching: lectures of architectural and urban design. Projects: author or co-author of more than 30 projects of architectural design and planning. 